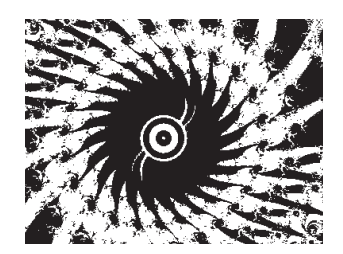

doi:10.5559/di.21.1.01

\title{
GENETSKI DOPRINOS INDIVIDUALNIM RAZLIKAMA U SUBJEKTIVNOJ DOBROBITI: METAANALIZA
}

Tena VUKASOVIĆ, Denis BRATKO, Ana BUTKOVIĆ Filozofski fakultet, Zagreb

UDK: 159.922.27:575

Izvorni znanstveni rad

Primljeno: 19. 7. 2010.

Cili ove metaanalize bio je sistematizirati postojeće znanje o genetskom doprinosu individualnim razlikama $u$ subjektivnoj dobrobiti (eng. subjective well-being) te dati smjernice za buduća istraživanja. Subjektivna dobrobit predstavlja tendenciju ka pozitivnim kognitivnim i afektivnim evaluacijama vlastita život. Dosadašnja istraživanja na području genetike ponašanja pokazala su da su individualne razlike u subjektivnoj dobrobiti dijelom genetski posredovane. Ovisno o metodologiji (nacrt, mjerni instrument, statistička obradba), postoje određene varijacije $u$ indeksima heritabilnosti. U okviru metaanalize definirani su kriteriji uključivanja i isključivanja primarnih istraživanja, provedeno je pretraživanje literature te je identificirano 14 primarnih istraživanja. Pet istraživanja moralo je biti isključeno iz analize zbog zavisnih uzoraka. Prosječan indeks heritabilnosti subjektivne dobrobiti pokazuje da se oko $39 \%(k=10, Q(d f=9)=241,32$, $p<0,0001)$ varijance fenotipa subjektivne dobrobiti može pripisati genetskim doprinosima. Nakon provođenja korekcije za pristranost u objavljivanju, 32\% $(k=12, Q(d f=11)=392,83, p<0,0001)$ varijance fenotipa subjektivne dobrobiti može se pripisati genetskim doprinosima. Razmotrene su smjernice za buduća primarna istraživanja i ograničenja ove metaanalize.

Ključne riječi: metaanaliza, heritabilnost, subjektivna dobrobit, zadovoljstvo životom, genetika ponašanja

Tena Vukasović, Sveučilište u Zagrebu, Filozofski fakultet, Odsjek za psihologiju, I. Lučića 3, 10000 Zagreb, Hrvatska. E-mail: tvukasov@ffzg.hr 
Subjektivna dobrobit je termin koji u literaturi obuhvaća širok spektar čovjekova funkcioniranja te se može konceptualizirati i operacionalizirati na razne načine. Međutim, među istraživačima na tom području već dulje vlada slaganje oko strukture i vremenske stabilnosti ovoga konstrukta (Diener, 1984.; Pavot i Diener, 1993.; Diener i sur., 1999.). Struktura subjektivne dobrobiti može se podijeliti na kognitivnu komponentu (evaluacija zadovoljstva životom) i emocionalnu komponentu (doživljaj ugodnog i odsutnost neugodnog afekta). Iz perspektive vremenske stabilnosti možemo govoriti o dugotrajnom aspektu (stabilni životni uvjeti, ličnost), srednje dugom aspektu (nedavni ili aktualni životni uvjeti, posao) i kratkotrajnom aspektu (raspoloženje). Dakle, osoba koja je više na dimenziji subjektivne dobrobiti, zadovoljna je svojim životom te češće doživljava ugodne, a rjeđe neugodne emocije.

Ispitivanje heritabilnosti vezano je uz područje genetike ponašanja, koje se bavi istraživanjem varijacija u ponašanju uvjetovanih genetskim i okolinskim doprinosima. Teorija kvantitativne genetike govori o etiologiji individualnih razlika $u$ ponašanju i predstavlja osnovu bihevioralno genetičkih istraživanja, u kojima pokušava objasniti individualne razlike na statistički način. Vrijednosti o kojima se govori u okviru kvantitativne genetike temelje se na varijancama, pri čemu fenotip predstavlja ukupnu varijancu $\left(V_{f}\right)$, a o relativnom genetskom $\left(V_{g}\right)$ i okolinskom doprinosu $\left(V_{o}\right)$ na razvoj fenotipa zaključujemo indirektno, na temelju sličnosti različito bliskih srodnika. Indeks heritabilnosti ključni je statistički pokazatelj na području genetike ponašanja, jer upućuje na proporciju fenotipske varijance koja se može pripisati genotipskoj varijanci $\left(h^{2}=V_{g} / V_{f}\right)$. Stubbe i sur. (2005.) utvrdili su da veći genetski doprinos postoji za dugotrajni aspekt subjektivne dobrobiti, dok je kod srednje dugog i kratkotrajnog aspekta veći okolinski doprinos.

Kao što je i ranije navedeno, subjektivnu dobrobit razni autori engleskoga govornog područja označavaju različitim terminima: sreća (eng. happiness), subjektivna dobrobit (eng. subjective well-being), zadovoljstvo životom (eng. life satisfaction), kvaliteta života (eng. quality of life) ili čak kao osobinu ličnosti (eng. $M P Q-W B)$. U istraživanju Bartels i Boomsme (2009.) uspoređivane su četiri mjere subjektivne dobrobiti, pa su autorice zaključile da su isti setovi gena u pozadini umjerenih do visokih fenotipskih korelacija, što implicira da se mjere subjektivne dobrobiti na genotipskoj razini ne razlikuju te da je stoga usporedba rezultata dobivenih njihovim korištenjem opravdana. Zaključile su da se u budućim istraživanjima treba usmjeriti na kompleksni međuodnos gena i okoline, a ne na to koju mjeru subjektivne dobrobiti odabrati. 
DRUŠ. ISTRAŽ. ZAGREB GOD. 21 (2012), BR. 1 (115),

STR. 1-17

VUKASOVIĆ, T., BRATKO, D., BUTKOVIĆ, A.: GÉNETSKI DOPRINOS

$\rightarrow$ SLIKA 1

Bazična razina i individualni raspon subjektivne dobrobiti
Prema teoriji bazične razine subjektivne dobrobiti, svatko od nas ima bazičnu razinu subjektivne dobrobiti (Lucas, 2007.; Diener i sur., 2006.; Lucas i sur., 2003.), a prema teoriji hedonističkoga kruga (eng. hedonic treadmill theory), imamo i individualni raspon unutar kojega naš subjektivni doživljaj sreće varira, ovisno o okolinskim uvjetima i događajima vraćajući se uvijek na bazičnu razinu (Brickman i Campbell, 1971.; Myers i Diener, 1995.), kao što je grafički prikazano na slici 1. Tellegen i sur. (1988.) među prvim su autorima koji su ispitivali subjektivnu dobrobit iz perspektive genetike ponašanja te su došli do zaključka da indeks heritabilnosti subjektivne dobrobiti iznosi 0,48.

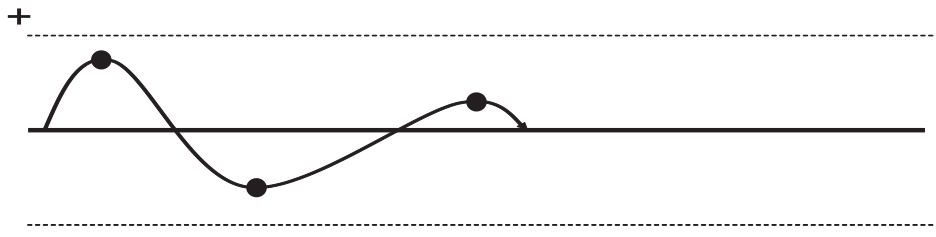

Isti autori, nakon desetljeća istraživanja na tom području, navode kako je neupitno da ugodni događaji (npr. dobitak na lotu, polaganje ispita, veća plaća) dovode do većega subjektivnog osjećaja dobrobiti, kao što i neugodni događaji (npr. otkaz, razvod) snižavaju raspoloženje i osjećaj dobrobiti, ali utjecaj takvih događaja prolazne je naravi te fluktuira oko stabilne bazične razine koja je karakteristična za svaku osobu. Međutim, autori završavaju determinističkom tvrdnjom da su naši pokušaji da budemo sretniji jednako uzaludni kao i naši pokušaji da budemo viši, pa su stoga i kontraproduktivni (Lykken i Tellegen, 1996.). S druge strane, Hamer (1996., str. 126) ima bitno pozitivnije gledanje na iste nalaze: "Iako geni određuju našu prosječnu bazičnu razinu za subjektivni doživljaj sreće, ne određuju gdje se unutar našega individualnog raspona nalazimo u nekom trenutku". Osvrnimo se na trenutak na primjer visine koji navode Lykken i Tellegen. Tjelesna visina primjer je visoko heritabilne ljudske osobine s indeksom heritabilnosti između 60 i 90\%, ovisno o populaciji (Silventoinen i sur., 2000.; Macgregor i sur., 2008.). Međutim, čak i kod visine okolinski doprinos nije zanemariv, nego iznosi između 10 i $40 \%$. Isto vrijedi i za subjektivni doživljaj sreće - naša bazična razina subjektivne dobrobiti dijelom je genetski određena, ali ako možemo utjecati na vlastito raspoloženje i subjektivnu dobrobit, zašto ih ne bismo povećali? Viši subjektivni doživljaj dobrobiti čini nam život ugodnijim, pa zašto ne težiti tome, makar povremeno?!

S obzirom na to da se produkcija znanstvenih radova eksponencijalno povećava, postaje sve teže pratiti aktualne tren- 
DRUŠ. ISTRAŽ. ZAGREB GOD. 21 (2012) BR. 1 (115),

STR. $1-17$

VUKASOVIĆ, T., BRATKO, D., BUTKOVIĆ, A.: GÉNETSKI DOPRINOS. dove i otkrića na nekom znanstvenom području, ali i donijeti zaključke uz postojanje kontradiktornih nalaza. U takvoj nam situaciji metaanaliza, kao tehnika, može biti vrlo vrijedna jer omogućuje sintezu postojećih nalaza i usmjeravanje budućih primarnih istraživanja. Koraci koji čine postupak metaanalize jesu: formulacija problema, pretraživanje literature, kodiranje, izračunavanje veličine učinka, dodatne analize (potraga za moderatorima, korekcija za pristranost $\mathrm{u}$ objavljivanju), interpretacija i publikacija. U svakom od koraka metaanalitičar mora donijeti odluke koje mogu utjecati na daljnji ishod metaanalize te stoga mora biti stručnjak $u$ samom postupku metaanalize, ali i na području na kojem se metaanaliza provodi. Svi koraci moraju biti dokumentirani i jasni kroz jednoznačno definirane kriterije uključivanja i isključivanja primarnih istraživanja, kodiranje svih relevantnih podataka, primjenu adekvatnih statističkih postupaka te uz svijest o potencijalnom izvoru invalidnosti (pristranost prilikom objavljivanja) i potrebnim korektivnim postupcima.

Budući da je do danas proveden veći broj pojedinačnih istraživanja o heritabilnosti subjektivne dobrobiti, moguće je sintetizirati postojeće nalaze i pokušati usmjeriti buduća istraživanja u području. Cilj ovog istraživanje bio je utvrditi prosječan indeks heritabilnosti subjektivne dobrobiti provedbom metaanalize.

\section{METODOLOGIJA}

\section{Pretraživanje literature}

Pretraživanje literature, s ciljem lociranja svih dostupnih primarnih istraživanja, mora biti provedeno maksimalno opsežno i detaljno, uz upotrebu raznih izvora podataka. U provedbi ove metaanalize iskorišteni su sljedeći izvori: elektroničke baze podataka EBSCOhost, PsycINFO, Hrčak i Ethos, pri čemu su ključne riječi: well-being, wellbeing, heritability, subjektivna dobrobit, heritabilnost. Na temelju referenci lociranih radova provedeno je daljnje pretraživanje literature. Kao konačan korak provedeno je pretraživanje konferencijskih priopćenja.

\section{Kriteriji uključivanja i isključivanja}

Metaanaliza ne može biti kvalitetno provedena ako nisu zadovoljeni osnovni preduvjeti za njezino provođenje te ako se njezini zaključci temelje na nekvalitetnim primarnim istraživanjima. Da bi primarno istraživanje bilo uključeno $u$ metaanalizu, mora zadovoljavati kriterije uključivanja te ne smije zadovoljavati kriterije isključivanja. Kriteriji za uključivanje primarnih istraživanja u ovu metaanalizu bili su: korištenje mjere subjektivne dobrobiti, navođenje indeksa heritabilno- 
DRUŠ. ISTRAŽ. ZAGREB GOD. 21 (2012), BR. 1 (115)

STR. 1-17

VUKASOVIĆ, T., BRATKO, D., BUTKOVIĆ, A.: GENETSKI DOPRINOS sti i bihevioralno genetički nacrt istraživanja (studija blizanaca, porodična studija ili studija usvajanja). Pošto je provedeno pretraživanje literature, locirano je 14 primarnih istraživanja koja su zadovoljavala kriterije uključivanja (13 znanstvenih članaka, 1 konferencijsko izlaganje). Kriteriji isključivanja primarnih istraživanja iz ove metaanalize bili su: nedostatak opisa uzorka (broj ispitanika, dob ispitanika, spolna zastupljenost) i zavisnost uzoraka. Ako je u jednom radu navedeno više veličina učinaka dobivenih na istom uzorku, odabrana je jedna mjera (psihometrijski najvaljanija). Ako se ista grupa autora u različitim radovima služila istim uzorkom, isključeni su zavisni uzorci odabirom jednog rada (bihevioralno genetički najinformativniji uzorak). Nakon isključivanja primarnih istraživanja koja su zadovoljila neki od kriterija isključivanja, zadržano je 9 primarnih istraživanja (8 znanstvenih članaka, 1 konferencijsko izlaganje). Budući da u jednom istraživanju (Harris i sur., 1992.) postoje dva nezavisna uzorka, iz tog istraživanja uzete su dvije nezavisne veličine učinka. U daljnjem tekstu mlađi uzorak ispitanika (do 65 godina) bit će označen kao Harris i sur., 1992. - prvi uzorak, a stariji uzorak (stariji od 65 godina) kao Harris i sur., 1992. - drugi uzorak. Dakle, uzorak ove metaanalize čini 10 nezavisnih veličina učinaka iz 9 primarnih istraživanja, od čega je 8 znanstvenih članaka i 1 konferencijsko izlaganje. Osnovne karakteristike uzorka prikazane su u Tablici 1.

Veličina uzorka u pojedinom istraživanju upućuje na broj jedinica analize, a ne na ukupan broj ispitanika. Naime, u studijama blizanaca jedinica analize je broj parova blizanaca (BO, $\mathrm{BZ})$, u porodičnim studijama broj obitelji (BZ i O), a u obiteljskim studijama broj parova roditelj-dijete (R i O). Ukupan broj jedinica analize uključenih u metaanalizu iznosi 11 991, dok ukupan broj ispitanika iznosi oko 30 000. Dobni raspon obuhvaćen ovim primarnim istraživanjima kreće se od 12 do 88 godina.

Istraživanja koja su isključena iz metaanalize isključena su zbog zavisnih uzoraka, tj. zbog potpunog ili djelomičnog preklapanja uzorka s uzorkom korištenim u istraživanju uključenom u metaanalizu. Istraživanje Bergeman i sur. (1991.) isključeno je jer se uzorak preklapa s uzorkom korištenim u Harris i sur. (1992.) - oba su dio Švedskog registra blizanaca/usvajanja te su uključeni sudionici iz ankete 1984. godine. U metaanalizu je uključeno samo istraživanje Harris i sur. (1992.) jer ima veći uzorak te omogućuje korištenje dviju nezavisnih veličina učinka (za mlađe od 65 godina i za starije od 65 godina). Istraživanja Tellegena i sur. (1988.) te McGuea i sur. (1993.) isključena su iz metaanalize jer su koristila uzorak iz Minnesota registra blizanaca, koji se preklapa s uzorcima iz uključenih istraživanja Lykkena i Tellegena (1996.) te Finkel i McGuea 
DRUŠ. ISTRAŽ. ZAGREB BR. 1 (115), STR. 1-17

VUKASOVIĆ, T., BRATKO, D., BUTKOVIĆ, A.: GÉNETSKI DO'PRINOS...

\section{Kodiranje}

(1) TABLICA 1

Osnovne karakteristike uzorka primarnih istraživanja uključenih $\mathrm{u}$ metaanalizu GOD. 21 (2012)

(1997.). Finkel i McGue (1997.) imaju najopsežniji uzorak dvojajčanih blizanaca, a Lykken i Tellegen (1996.) najveći broj parova jednojajčanih blizanaca odraslih odvojeno.

Uzorci blizanaca iz Norveškog registra $u$ istraživanjima Røysamba i sur. (2002.), Røysamba i sur. (2003.) te Nes i sur. (2006.) dijelom se preklapaju. Odlučeno je da će u metaanalizu biti uključeno primarno istraživanje Røysamba i sur. (2003.) zbog najinformativnijeg uzorka.

Kodni plan izrađuje se u fazi planiranja istraživanja na temelju poznavanja postupka metaanalize i područja na kojem se metaanaliza provodi. Nužno je u kodni plan uključiti sve informacije koje će u kasnijim analizama omogućiti odgovor na probleme istraživanja te ispitivanje potencijalnog utjecaja moderatorskih varijabli. U toku provedbe metaanalize potrebno je modificirati kodni plan ako se pokaže potreba za kodiranjem dodatnih informacija (Lipsey i Wilson, 2001.). Informacije koje su kodirane za svako primarno istraživanje jesu: autor/i istraživanja, godina izdanja, naslov, vrsta publikacije, država u kojoj je istraživanje provedeno, projekt kojem autor/i pripadaju, vrsta nacrta, broj ispitanika, broj ili postotak ženskih ispitanika, dob ispitanika, upitnička mjera, statistički postupak, veličina učinka i mjera raspršenja. Klasični problem koji se vezuje uz metaanalizu jest nemogućnost kodiranja svih izvornih statističkih parametara zbog njihova nenavođenja u primarnim istraživanjima. U ovoj metaanalizi taj se problem odnosio na nenavođenje standardne pogreške u svim istraživanjima te se $u$ tom slučaju koristio izračun prosječne vrijednosti standardne pogreške prema adekvatnoj formuli (Li i sur., 2003.). Prva i treća autorica nezavisno su kodirale sva primarna istraživanja prema jasno definiranom kodnom planu i uputama za kodiranje.

\begin{tabular}{lllllll}
\hline \multicolumn{1}{c}{ Autori } & God. & Uzorak & Mjera & Nacrt & $h^{2}$ & $n$ SDe \\
\hline 1. Lykken i Tellegen & 1996. Minnesota registar & MPQ-WB & BO & 0,52 & 75 & 0,100 \\
2. Finkel i McGue & 1997. Minnesota registar & MPQ-WB & BZ i O & 0,40 & 1257 & 0,025 \\
3. Røysamb i sur. & 2003. Norveški registar & SWB & BZ & 0,44 & 3288 & 0,015 \\
4. Weiss, Bates i Luciano & 2008. MIDUS & SWB & BZ & 0,22 & 973 & 0,028 \\
5. Harris i sur. - prvi uzorak & 1992. SATSA & LSI-Z & BZ i BO & 0,00 & 382 & 0,045 \\
6. Harris i sur. - drugi uzorak & 1992. SATSA & LSI-Z & BZ i BO & 0,48 & 182 & 0,076 \\
7. Stubbe i sur. & 2005. Nizozemski registar & SWLS & BZ i O & 0,38 & 3072 & 0,016 \\
8. Bartels i Boomsma & 2009. Nizozemski registar & SWLS & BZ i O & 0,47 & 2157 & 0,019 \\
9. Casas i sur. & 2008. španjolske obitelji & 1 pitanje & R i D & 0,17 & 266 & 0,055 \\
10. Bratko i Butković & 2009. hrvatski uzorak blizanaca & SWLS & BZ & 0,83 & 339 & 0,048
\end{tabular}

MIDUS-MacArthur Foundation Survey of Midlife Development (SAD); SATSA-Swedish Adoption/Twin Study of Aging; BO-blizanci odrasli odvojeno; BZ-blizanci odrasli zajedno; O-članovi obitelji; R i D-roditelji i dijete; $h^{2}$-indeks heritabilnosti, $n$-broj jedinica analize, SDe-standardna pogreška 


\section{OBRADBA PODATAKA}

\section{Preliminarne analize}

Preliminarna analiza podataka uključivala je analizu slaganja dvaju kodera kao nužan kriterij valjanosti procesa kodiranja. Moguće je izračunati različite koeficijente slaganja, među kojima je najjednostavniji Pearsonov koeficijent korelacije, a među najpouzdanijima Krippendorffov alpha-koeficijent pouzdanosti (Hayes i Krippendorff, 2007.). Pearsonov koeficijent korelacije nezavisno kodiranih veličina učinaka iznosio je 0,89 , a Krippendorffov alpha 0,93 . Neslaganje kodera odnosilo se na različito kodirane veličine učinka u istraživanjima Lykkena i Tellegena (1996.), Casasa i sur. (2008.) te Weissa i sur. (2008.). Potom se pristupilo zajedničkom analiziranju navedenih veličina učinka, utvrđivanju izvora neslaganja i usaglašavanju konačne veličine učinka. Neslaganje u istraživanju Lykkena i Tellegena (1996.) bilo je posljedica kodiranja pogrešne vrijednosti kao indeksa heritabilnosti $(0,48)$ te je nakon rasprave usaglašeno kodiranje veličine učinka 0,52 . Neslaganje kod istraživanja Casasa i sur. (2008.) bilo je rezultat zaokruživanja na veću $(0,17)$, tj. manju vrijednost $(0,16)$. Usklađeno je uvrštavanje vrijednosti 0,17 kao veličine učinka jer je izvorno indeks iznosio 0,166 . Neslaganje u istraživanju Weissa i sur. (2008.) posljedica je različitih načina izračuna indeksa heritabilnosti na temelju podataka navedenih u radu. Indeks heritabilnosti može se izračunati na dva načina: zbrajanjem kvadriranih standardnih koeficijenata na dijagramu traga $(0,22)$ ili Falconerovom formulom $(0,54)$. U uputi za kodiranje naveden je redoslijed metoda izračuna indeksa heritabilnosti, $\mathrm{u}$ slučaju kada se izračun može provesti na više načina, prema pouzdanosti metode izračuna: 1. strukturalno modeliranje, 2 . korelacija jednojajčanih blizanaca odraslih odvojeno, 3. Falconerova formula, 4. indeks familijarnosti. Usklađeno je uvrštavanje vrijednosti 0,22, koja je rezultat strukturalnoga modeliranja. Stock i sur. (1982.) kao donju granicu zadovoljavajuće razine slaganja nezavisnih kodera navode koeficijent korelacije 0,80 . Međutim, sastavni dio kodiranja uključuje i analizu izvora neslaganja nakon kodiranja te usuglašavanje veličine učinka ako se utvrdi da je izvor neslaganja pogreška ili eventualno različiti načini kodiranja (Stock i sur., 1982.; Roth i sur., 2005.), što je učinjeno i u ovoj metaanalizi. Ako stupanj slaganja nezavisnih kodera nije zadovoljavao, pristupilo bi se korigiranju kodnoga plana, uputa za kodiranje te ponovnom kodiranju podataka.

\section{Analiza podataka}

Analiza podataka provedena je u paketu metafor računalnoga programa $R$, koji omogućuje analizu u okviru dvaju statističkih i logičkih modela: modela fiksnog učinka (eng. fixed-effect model) i modela slučajnih učinaka (eng. random-effects model). 
DRUŠ. ISTRAŽ. ZAGREB GOD. 21 (2012) BR. 1 (115),

STR. $1-17$

VUKASOVIĆ, T., BRATKO, D., BUTKOVIĆ, A.: GÉNETSKI DOPRINOS...
Odabir odgovarajućega modela ovisi prije svega o teorijskim očekivanjima $u$ izvorima pogreške, tj. varijabiliteta, a tek potom o statističkom pokazatelju heterogenosti veličina učinaka. Najprije će biti opisan statistički postupak, a potom logika pojedinoga modela. Statistički postupak počinje testiranjem heterogenosti, tj. provedbom Q-testa, kojim testiramo pripadaju li sve veličine učinaka istoj populaciji - jesu li homogene. Ako Q-test nije statistički značajan, preporučuje se primjena modela fiksnog učinka. Ako je Q-test statistički značajan, preporučuje se upotreba modela slučajnih učinaka. Postoji preporuka da se u slučaju neznačajnoga Q-testa i uz malen uzorak (malen broj primarnih istraživanja) ipak rabi model slučajnih učinaka, jer kod maloga broja primarnih istraživanja Q-test može imati premalenu statističku snagu za detektiranje razlika koje postoje. Međutim, odabir modela ne bi se smio temeljiti isključivo na vrijednosti Q-testa nego i na slaganju podataka s teorijskim pretpostavkama fiksnoga modela i modela slučajnih učinaka (Borenstein i sur., 2009.).

Prema logici modela fiksnog učinka, pretpostavljamo da sva primarna istraživanja mjere jedan, isti pravi efekt ili učinak, a metaanalizom procjenjujemo taj pravi učinak. Druga je pretpostavka da je jedini izvor varijabiliteta između istraživanja pogreška uzorkovanja. Statističkom analizom dolazimo do procijenjenoga pravog učinka i intervala pouzdanosti procijenjenoga pravog učinka.

Logika modela slučajnih učinaka polazi od drukčijih pretpostavki: pretpostavlja normalnu distribuciju pravih veličina učinaka (eng. true effect size), različite prave veličine učinaka u svakom primarnom istraživanju te postojanje procijenjene prosječne prave veličine učinka. Drukčije rečeno, svako primarno istraživanje ima vlastitu pravu veličinu učinka te opaženu veličinu učinka, koja, u odnosu na pravu veličinu učinka, varira po slučaju. Budući da se prave veličine učinaka normalno distribuiraju, procjenom aritmetičke sredine te distribucije dobivamo procijenjenu prosječnu pravu veličinu učinka.

Budući da je indeks heritabilnosti populacijski parametar te pretpostavljamo da će u određenoj mjeri varirati od uzorka do uzorka, tj. od populacije do populacije, iz perspektive genetike ponašanja logičan izbor modela jest model slučajnih učinaka, koji uzima u obzir dodatan (iako neidentificiran) izvor varijabiliteta među veličinama učinka.

\section{REZULTATI I RASPRAVA}

Q-test je bio statistički značajan $(k=10, Q(d f=9)=241,32$, $\mathrm{p}<0,0001$ ), što znači da veličine učinaka ne pripadaju istoj populaciji, pa je preporuka primijeniti model slučajnih učinaka. Provedbom analize $\mathrm{u}$ okviru modela slučajnih učinaka procijenjena veličina učinka iznosila je 0,39 ( $\mathrm{SDe}=0,046$; IP $95 \%$ 
DRUŠ. ISTRAŽ. ZAGREB GOD. 21 (2012), BR. 1 (115)

STR. 1-17

VUKASOVIĆ, T., BRATKO, D., BUTKOVIĆ, A.: GÉNETSKI DO'PRINOS

(1) SLIKA 2

Grafički prikaz

rezultata metaanalize u okviru modela slučajnih učinaka
$<0,30,0,48>$ ). Prosječan indeks heritabilnosti subjektivne dobrobiti pokazuje da se $39 \%$ varijance fenotipa subjektivne dobrobiti može pripisati genetskim doprinosima. Rezultati se mogu prikazati i grafički (vidi Sliku 2).

Na grafičkom prikazu prikazana je veličina učinka $\mathrm{i}$ interval pouzdanosti za svako primarno istraživanje uključeno u metaanalizu. Vidi se da ona istraživanja koja imaju veći uzorak (Røysamb i sur., 2003.; Stubbe i sur., 2005.; Bartels i Boomsma, 2009.) imaju i uže intervale pouzdanosti, tj. manju standardnu pogrešku, pa je njihova veličina učinka (crni kvadrat) relativno veća $u$ odnosu na veličine učinaka istraživanja s manjim brojem ispitanika (Lykken i Tellegen, 1996.; Harris i sur., 1992. - drugi uzorak; Casas i sur., 2008.). To znači da računalni program $R$, prilikom izračuna procijenjene prosječne prave veličine učinka, istraživanjima s većim brojem ispitanika i užim intervalom pouzdanosti daje veći ponder. Romb koji se nalazi na dnu grafičkoga prikaza predstavlja rezultat metaanalize, tj. procijenjenu prosječnu pravu veličinu učinka (VU=0,39), i interval pouzdanosti, u kojem, uz 95\% sigurnosti, možemo tvrditi da se nalazi procijenjeni pravi rezultat $(0,30,0,48)$.

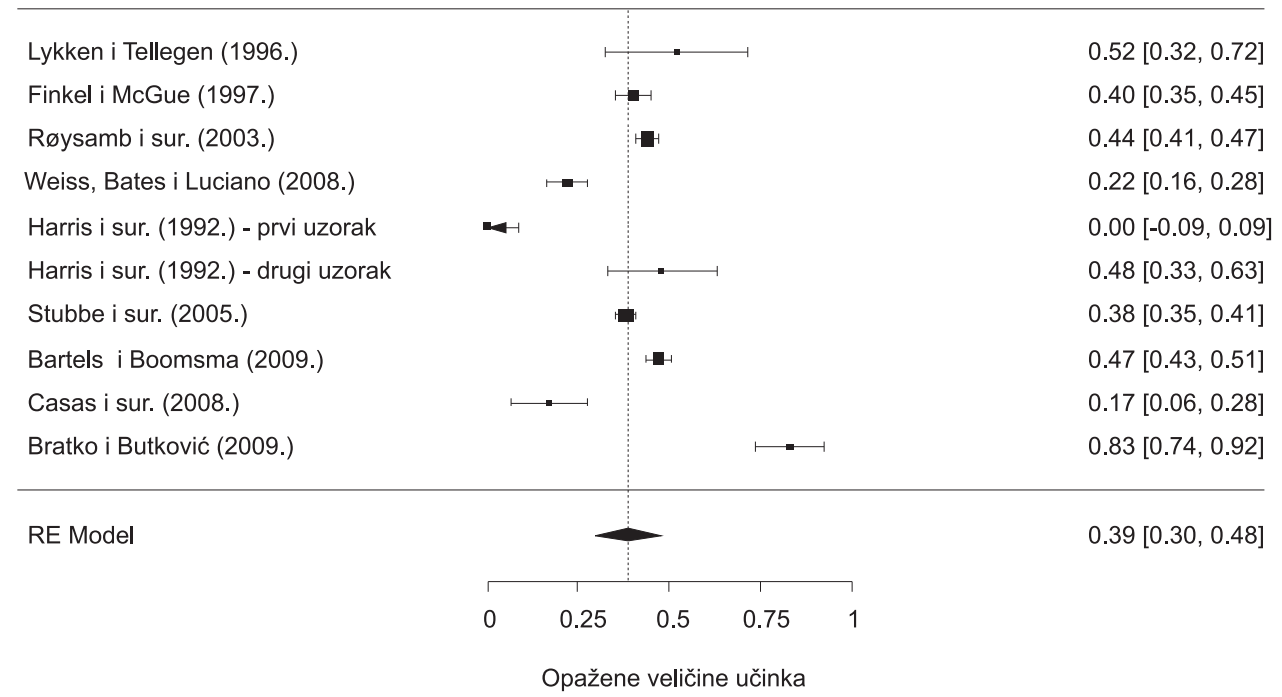

Budući da je Q-test potvrdio kako veličine učinaka ne pripadaju istoj populaciji, tj. da su heterogene, provjerili smo postoje li u distribuciji ekstremne vrijednosti (eng. outliers) koje potencijalno "umjetno" stvaraju heterogenost i čijim bismo isključivanjem iz metaanalize dobili realniju procjenu veličine učinka. Utvrđene su dvije ekstremne vrijednosti: 0,00 (Harris i sur., 1992. - prvi uzorak) i 0,83 (Bratko i Butković, 2009.). Ponovnom analizom navedenih radova nisu utvrđeni metodološki nedostaci koji bi mogli objasniti odstupanje i time opravdati isključivanje iz metaanalize. Lipsey i Wilson (2001.) 
DRUŠ. ISTRAŽ. ZAGREB GOD. 21 (2012) BR. 1 (115),

STR. $1-17$

VUKASOVIĆ, T., BRATKO D., BUTKOVIĆ, A.: GÉNETSKI DOPRINOS... navode kako je, u slučaju postojanja nekoliko ekstremnih vrijednosti, moguće provesti dodatnu analizu isključivanjem tih vrijednosti iz uzorka, ponovnom provedbom analize te usporedbom rezultata. Isključivanjem istraživanja Harris i sur. (1992.) - prvi uzorak te Bratka i Butković (2009.) iz metaanalize Q-test je ostao statistički značajan $(\mathrm{k}=8, \mathrm{Q}(\mathrm{df}=7)=82,40$, $\mathrm{p}<0,0001)$, dok je procijenjena prosječna prava veličina učinka iznosila 0,38 (SDe=0,033; IP 95\% <0,31, 0,44>). Usporedbom rezultata originalne i dodatne analize zaključeno je kako će primarna istraživanja Harris i sur. (1992.) - prvi uzorak te Bratka i Butković (2009.) biti zadržana u uzorku, jer njihovi odstupajući rezultati nisu posljedica metodoloških nedostataka niti predstavljaju statistički značajan izvor heterogenosti veličina učinaka u uzorku.

\section{KOREKCIJA PRISTRANOSTI U OBJAVLJIVANJU}

Budući da se i uz najopsežnije pretraživanje literature ne mogu locirati sva istraživanja provedena na nekom području, rezultate metaanalize treba podvrgnuti korekciji zbog pristranosti u objavljivanju. Paket metafor omogućuje izračun različitih metoda korekcije pristranosti u objavljivanju: Sigurno neznačajni N (eng. Fail Safe N), Dijagram lijevka (eng. Funnel plot) te Oduzmi i dodaj (eng. Trim \& Fill). Metodu Sigurno neznačajni N uveo je Rosenthal, razvio Orwin (Rosenthal, 1979.; Orwin, 1983.), a omogućuje nam odgovor na pitanje koliko je dodatnih primarnih istraživanja potrebno da bi se procijenjena veličina učinka smanjila na nulu, tj. da ne bi bila statistički značajno različita od nule. Naravno, što je više istraživanja potrebno, to su naši rezultati stabilniji. Dijagram lijevka (eng. funnel = lijevak, brodski dimnjak) grafički je prikaz svake veličine učinka uz neku mjeru utjecaja te veličine učinka na metaanalizu (n, SDe). Simetričan oblik lijevka očekivani je oblik raspršenja veličina učinaka ako ne postoji pristranost $u$ objavljivanju (Begg, 1994.). Logika je da je provedeno više primarnih istraživanja s manjim uzorkom (n) i većim varijabilitetom (SDe), gdje slučajne varijacije imaju veći utjecaj na veličinu učinka, a da je provedeno manje istraživanja s velikim uzorkom i manjim varijabilitetom jer su takva istraživanja vremenski i financijski zahtjevnija. Primarna istraživanja s manjim uzorkom i istraživanja sa statistički neznačajnim rezultatima manje će vjerojatno biti objavljena (zbog česte odluke uredništva časopisa o neobjavljivanju statistički neznačajnih nalaza), pa će zato u Dijagramu lijevka postojati manje veličina učinka (primarnih istraživanja) u lijevom donjem kutu grafičkoga prikaza, što dovodi do asimetrije grafa. Oduzmi i dodaj metoda je za evaluaciju pristranosti Dijagrama lijevka, kojom se najprije procjenjuje broj "asimetričnih" veličina učinaka na desnoj 
DRUŠ. ISTRAŽ. ZAGREB GOD. 21 (2012), BR. 1 (115),

STR. 1-17

VUKASOVIĆ, T., BRATKO, D., BUTKOVIĆ, A.: GÉNETSKI DOPRINOS.

(1) SLIKA 3

Dijagram lijevka: grafički prikaz (ne)pristranosti u objavljivanju strani grafa, tj. veličina učinaka koje nemaju "par" na lijevoj strani (Duval i Tweedie, 2000.). Potom se "asimetrične" veličine učinka uklanjaju s grafa i lijevak ostaje simetričan. U sljedećem se koraku "asimetrične" veličine učinka vraćaju, pa se s lijeve strane dodaju njihove simulirane "zrcalne slike", tj. parovi s lijeve strane. Završni je korak izračunavanje prilagođenih vrijednosti procjene veličine učinka i mjera raspršenja na simuliranom uzorku s dodanim veličinama učinka.

Metoda Sigurno neznačajni N izračunana je prema Orwinovu načelu te pruža informaciju da je 381 primarno istraživanje s veličinom učinka nula $(\mathrm{VU}=0)$ potrebno uključiti u ovu metaanalizu da bi se procijenjena prosječna prava veličina učinka svela na veličinu učinka 0,01, a čak 3901 primarno istraživanje da bi se veličina učinka svela na 0,001 . Na slici 3 nalazi se Dijagram lijevka, na temelju kojega možemo vidjeti da veličine učinka nisu homogene, a također vidimo da u donjem lijevom kutu postoji manjak istraživanja. Metodom Oduzmi i dodaj procijenjeno je da u donjem lijevom kutu nedostaju dvije veličine učinka da bi lijevak bio simetričan. Uključivanjem dviju simuliranih veličina učinka u uzorak i ponovnom provedbom metaanalize procijenjena prosječna prava veličina učinka, korigirana za pristranost $u$ objavljivanju, iznosi $0,32(k=12, Q(d f=11)=392,83, p<0,0001)$. Drugim riječi$\mathrm{ma}$, uz korekciju pristranosti u objavljivanju, indeks heritabilnosti subjektivne dobrobiti pokazuje da se $32 \%$ varijance fenotipa subjektivne dobrobiti može pripisati genetskim doprinosima.

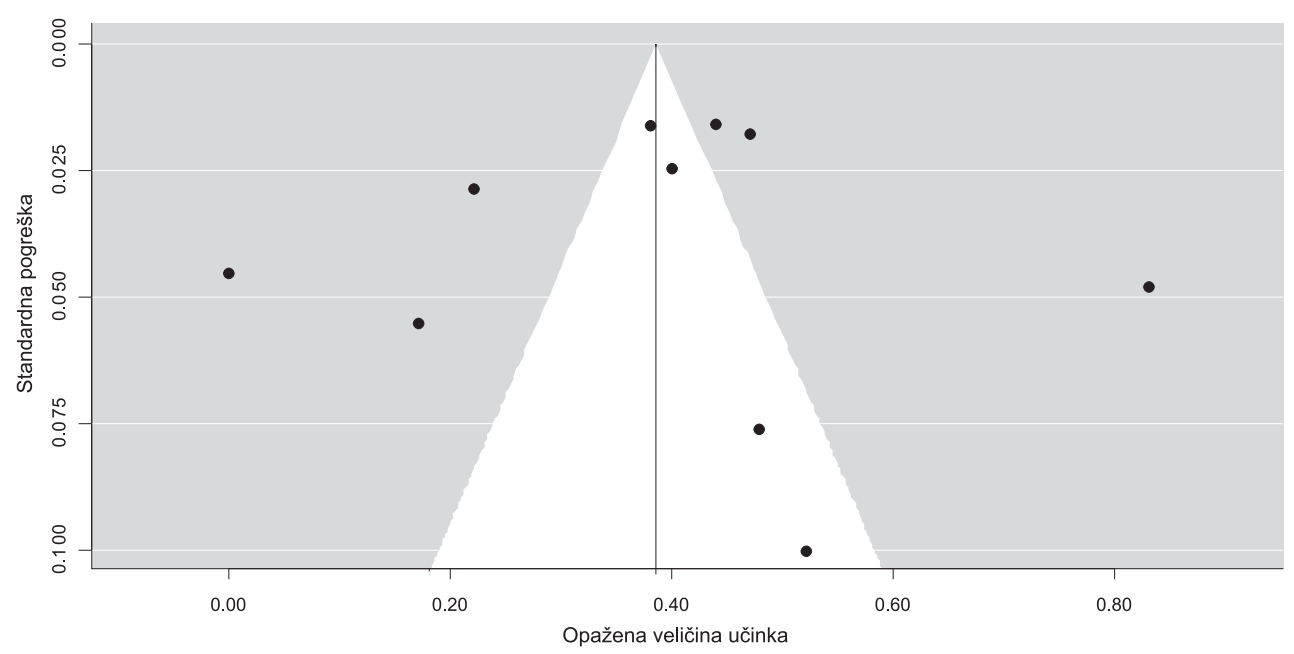

$\mathrm{Na}$ temelju dobivenih rezultata možemo reći da postoji genetska osnova subjektivne dobrobiti te da je relativni genetski doprinos individualnim razlikama u toj osobini oko $39 \%$ (uz korekciju 32\%). Ako na isti rezultat pogledamo iz druge 
DRUŠ. ISTRAŽ. ZAGREB GOD. 21 (2012) BR. 1 (115),

STR. $1-17$

VUKASOVIĆ, T., BRATKO D., BUTKOVIĆ, A.: GÉNETSKI DOPRINOS... perspektive, možemo reći da je relativni doprinos okoline na individualne razlike $\mathrm{u}$ subjektivnoj dobrobiti oko $61 \%$ (uz korekciju 68\%). Ako dobivene rezultate sagledamo iz konteksta ranije spomenute teorije bazične razine subjektivne dobrobiti i teorije hedonističkoga kruga (eng. hedonic treadmill theory), na temelju ove metaanalize možemo tvrditi da je potvrđen genetski doprinos individualnim razlikama u subjektivnoj dobrobiti kao i relativni doprinos okolinskih faktora. Valja napomenuti da su Diener i sur. (2006.), nakon desetljeća istraživanja na tom području, revidirali adaptacijsku teoriju subjektivne dobrobiti, ostavljajući dijelove originalne teorije hedonističkoga kruga netaknutima, ali uz pet važnih revizija: 1. bazična razina subjektivne dobrobiti nije neutralna, nego je kod većine ljudi pozitivna, 2 . postoje individualne razlike $u$ bazičnoj razini subjektivne dobrobiti, 3 . svaki aspekt subjektivne dobrobiti ima vlastitu bazičnu razinu, 4. bazična razina subjektivne dobrobiti može se promijeniti, 5 . postoje individualne razlike u vjerojatnosti i brzini adaptacije. Lykken (2007.) je u komentaru na reviziju koju su ponudili Diener i sur. (2006.) potvrdio da nalazi o heritabilnosti subjektivne dobrobiti potvrđuju 1., 2. i 5. dopunu originalne teorije, ali osporava dokaze na temelju kojih su autori formirali 3. i 4. dopunu. S druge strane, Lucas (2007.) ipak ustraje u tvrdnji da se bazična razina subjektivne dobrobiti može promijeniti.

Osvrnimo se sada na longitudinalno istraživanje McGuea i sur. (1993.), u kojem je ispitana stabilnost subjektivnoga doživljaja sreće u deset godina te je utvrđeno da je $80 \%$ varijacija stabilnoga dijela subjektivne dobrobiti kao osobine heritabilno. Hamer (1996., str. 125) isti je nalaz prokomentirao ovako: "Kako se osjećamo danas, podjednako je pod utjecajem genetskih i okolinskih faktora, ali kako ćemo se u prosjeku osjećati tijekom sljedećih deset godina, $80 \%$ je određeno našim genima". Drugim riječima, možemo reći da se ovaj nalaz može interpretirati kao potvrda stabilnosti bazične razine subjektivne dobrobiti na genotipskoj razini.

Dakle, ova je metaanaliza s većom statističkom snagom potvrdila ranije nalaze, prema kojima je bazična razina subjektivne dobrobiti dijelom genetski determinirana (39\%), a dijelom je rezultat okolinskog doprinosa (61\%). Međutim, ova pomalo deterministička tvrdnja o relativnom genetskom doprinosu zapravo je pozitivna. Naime, ranije je dokazano kako se većina ljudi smatra iznadprosječno sretnima, tj. za većinu ljudi njihova je bazična razina subjektivne dobrobiti emocionalno ugodna te ih čini sretnima (Lykken i Tellegen, 1996.; Diener i sur., 2006.). U tom slučaju, poželjno se u životu vraćati na vlastitu stabilnu razinu subjektivne dobrobiti, jer to znači da tendiramo prema sreći. 
Prosječan indeks heritabilnosti subjektivne dobrobiti pokazuje da se $39 \%$ varijance fenotipa subjektivne dobrobiti može pripisati genetskim doprinosima. Uz korekciju pristranosti u objavljivanju, indeks heritabilnosti subjektivne dobrobiti pokazuje da se $32 \%$ varijance fenotipa subjektivne dobrobiti može pripisati genetskim doprinosima. Osnovni nedostatak ove metaanalize odnosi se na skroman broj trenutačnih primarnih istraživanja $(k=10)$ koja zadovoljavaju kriterij nezavisnih uzoraka, pa onda i na nemogućnost provjere utjecaja moderatora, što bi bio najveći doprinos metaanalize. Drugi je nedostatak taj što u pretraživanje literature nisu uključene baze i časopisi neengleskoga govornog područja (osim hrvatskog). Iako su danas vodeći svjetski znanstveni časopisi uglavnom s engleskoga govornog područja, moguće je da smo zanemarili metodološki valjana istraživanja koja su objavljena u manje poznatim časopisima, a koja se ne nalaze u bazama EBSCOhost i PsycINFO.

Osim sintetiziranja postojećega znanja, metaanaliza omogućuje i definiranje smjernica za buduća primarna istraživanja, tj. što još treba napraviti na razini primarnih istraživanja kako bi se na razini metaanalize moglo doći do potpunih zaključaka. U ovoj metaanalizi nije odgovoreno na pitanje koje varijable imaju ulogu moderatora na procjenu heritabilnosti subjektivne dobrobiti, tj. što se nalazi u podlozi heterogenosti veličina učinaka. Jesu li to mjerni instrumenti različitih psihometrijskih karakteristika, vrste nacrta istraživanja, statističke metode izračuna indeksa heritabilnosti ili možda različite kulture u kojima su provedena primarna istraživanja - ta pitanja ostaju neodgovorena. Stoga bi smjernice koje možemo ponuditi autorima budućih istraživanja bile: provesti primarna istraživanja na nezavisnim uzorcima iz različitih kultura, $\mathrm{u}$ istraživanjima koristiti se nacrtima istraživanja i različitim (ali standardiziranim) mjernim instrumentima te navoditi vrijednosti veličine učinka (VU), standardne pogreške (SDe), intervala pouzdanosti (IP) i broja ispitanika (n) u radovima. Osnovna smjernica za urednike časopisa bila bi usvajanje politike objavljivanja i metodološki valjanih istraživanja s malim uzorcima i statistički neznačajnim nalazima, jer su nam i takva istraživanja potrebna kako bismo u metaanalizi dobili realnu procjenu veličine učinka. Pošto se identificiraju moderatori, preostaje usmjeriti se na ispitivanje interakcije specifičnih gena vezanih uz subjektivnu dobrobit i specifičnu okolinu.

Dakle, potrebno je provesti nova, metodološki valjana, primarna istraživanja na nezavisnim uzorcima, kako bi se njihovim uključivanjem u metaanalizu moglo odgovoriti na pitanje što je izvor varijabiliteta među veličinama učinka. Takva 
buduća metaanaliza, provedena na većem uzorku, omogućila bi identifikaciju metodoloških varijabli koje u funkciji moderatora utječu na veličinu učinka.

Bartels, M. i Boomsma, D. I. (2009.), Born to be Happy? The Etiology of Subjective Well-Being. Behavior Genetics, 39 (6): 605-615. doi:10. 1007/s10519-009-9294-8

Begg, C. B. (1994.), Publication Bias. U: H. Cooper i L. V. Hedges (ur.), The Handbook of Research Synthesis (str. 399-411), New York, Russell Sage Foundation.

Bergeman, C. S., Plomin, R., Pedersen, N. L. i McClearn, G. E. (1991.), Genetic Mediation of the Relationship between Social Support and Psychological Well-Being. Psychology E Aging, 6 (4): 640-646. doi:10. 1037//0882-7974.6.4.640

Borenstein, M., Hedges, L. V., Higgins, L. V. i Rothstein, H. R. (2009.), Introduction to Meta-Analysis, Chichester, UK, John Wiley \& Sons, Ltd. doi:10.1002/9780470743386

Bratko, D. i Butković, A. (2009.), Zadovoljstvo životom i genetika: Rezultati istraživanja blizanaca, 19. Dani Ramira i Zorana Bujasa: Program i sažeci priopćenja, Ljubotina, D., Kamenov, Ž., Mikac, U. i Urch, D. (ur.), Zagreb, Školska knjiga, str. 102.

Brickman, P. i Campbell, D. T. (1971.), Hedonic Relativism and Planning the Good Society. U: M. H. Appley (ur.), Adaptation Level Theory: A Symposium (str. 287-302), New York, Academic Press.

Casas, F., Coenders, G., Cummins, R. A., Gonzalez, M., Figuer, C. i Malo, S. (2008.), Does Subjective Well-Being Show a Relationship between Parents and Their Children? Journal of Happiness Studies, 9 (2): 197-205. doi:10.1007/s10902-007-9044-7

Diener, E. (1984.), Subjective Well-Being. Psychological Bulletin, 95 (3): 542-575. doi:10.1037//0033-2909.95.3.542

Diener, E., Lucas, R. E. i Scollon, C. N. (2006.), Beyond the Hedonic Treadmill: Revising the Adaptation Theory of Well-Being. American Psychologist, 61 (4): 305-314. doi:10.1037/0003-066X.61.4.305

Diener, E., Suh, E. M., Lucas, R. E. i Smith, H. L. (1999.), Subjective Well-Being: Three Decades of Progress. Psychological Bulletin, 125 (2): 276-302. doi:10.1037//0033-2909.125.2.276

Duval, S. i Tweedie, R. (2000.), Trim and Fill: A Simple Funnel-Plot-Based Method of Testing and Adjusting for Publication Bias in Meta-Analysis. Biometrics, 56 (2): 455-463. doi:10.1111/j.0006-341X.2000.00455.x

Finkel, D. i McGue, M. (1997.), Sex Differences and Nonadditivity in Heritability of the Multidimensional Personality Questionnaire Scales. Journal of Personality and Social Psychology, 72 (4): 929-938. doi:10. 1037//0022-3514.72.4.929

Hamer, D. H. (1996.), The Heritability of Happiness. Nature Genetics, 14: 125-126. doi:10.1038/ng1096-125

Harris, J. R., Pedersen, N. L., Stacey, C., McClearn, G. E. i Nesselroade, J. R. (1992.), Age Differences in the Etiology of the Relationship between Life Satisfaction and Self-Rated Health. Journal of Aging and Health, 4 (3): 349-368. doi:10.1177/089826439200400302 
DRUŠ. ISTRAŽ. ZAGREB GOD. 21 (2012), BR. 1 (115), STR. $1-17$

VUKASOVIĆ, T., BRATKO, D., BUTKOVIĆ, A.: GÉNETSKI DOPRINOS
Hayes, A. F. i Krippendorff, K. (2007.), Answering the Call for a Standard Reliability Measure for Coding Data. Communication Methods and Measures, 1 (1): 77-89. doi:10.1080/19312450709336664

Li, M. D., Cheng, R., Ma, J. Z. i Swan, G. E. (2003.), A Meta-Analysis of Estimated Genetic and Environmental Effects on Smoking Behavior in Male and Female Adult Twins. Addiction, 98 (1): 23-31. doi:10. 1046/j.1360-0443.2003.00295.x

Lipsey, M. W. i Wilson, D. B. (2001.), Practical Meta-Analysis, London, SAGE Publications.

Lucas, R. E. (2007.), Adaptation and the Set-Point Model of Subjective Well-Being. Does Happiness Change After Major Life Events? Current Directions in Psychological Science, 16 (2): 75-79. doi:10. 1111/j.1467-8721.2007.00479.x

Lucas, R. E., Clark, A. E., Georgellis, Y. i Diener, E. (2003.), Reexamining Adaptation and the Set Point Model of Happiness: Reactions to Changes in Marital Status. Journal of Personality $\mathcal{E}$ Social Psychology, 84 (3): 527-539. doi:10.1037//0022-3514.84.3.527

Lykken, D. T. (2007.), "Beyond the Hedonic Treadmill: Revising the Adaptation Theory of Well-Being": Comment on Diener, Lucas, and Scollon (2006.), American Psychologist, 62 (6): 611-612. doi:10.1037/ 0003-066X62.6.611

Lykken, D. T. i Tellegen, A. (1996.), Happiness Is a Stochastic Phenomenon. Psychological Science, 7 (3): 186-189. doi:10.1111/j.1467-9280.1996. tb00355.x

Macgregor, S., Hottenga, J. J., Lind, P. A., Suchiman, H. E. D., Willemsen, G., Slagboom, P. E., Montgomery, G. W., Martin, N. G., Visscher, P. M. i Boomsma, D. I. (2008.), Vitamin D Receptor Gene Polymorphisms Have Negligible Effect on Human Height. Twin Research and Human Genetics, 11 (5): 488-494.

McGue, M., Bacon, S. i Lykken, D. T. (1993.), Personality Stability and Change in Early Adulthood: A Behavioral Genetic Analysis. Developmental Psychology, 29 (1): 96-109. doi:10.1037//0012-1649.29.1.96

Myers, D. G. i Diener, E. (1995.), Who is Happy? Psychological Science, 6 (1): 10-19. doi:10.1111/j.1467-9280.1995.tb00298.x

Nes, R. B., Røysamb, E., Tambs, K., Harris, J. R. i Reichborn-Kjennerud, T. (2006.), Subjective Well-Being: Genetic and Environmental Contributions to Stability and Change. Psychological Medicine, 36 (7): 1033-1042. doi:10.1017/S0033291706007409

Orwin, R. G. (1983.), A Fail-Safe N for Effect Size in Meta-Analysis. Journal of Educational Statistics, 8 (2): 157-159. doi:10.2307/1164923

Pavot, W. i Diener, E. (1993.), Review of the Satisfaction with Life Scale. Psychological Assessment, 5 (2): 164-172. doi:10.1037//1040-3590. 5.2.164

Rosenthal, R. (1979.), The "File-Drawer Problem" and Tolerance for Null Results. Psychological Bulletin, 86 (3): 638-641. doi:10.1037//00332909.86.3.638

Roth, P. L., Bobko, P. i McFarland, L. A. (2005.), A Meta-Analysis of Work Sample Test Validity: Updating and Integrating Some Classic Literature. Personnel Psychology, 58 (4): 1009-1037. doi:10.1111/j.1744-6570. 2005.00714.x 
DRUŠ. ISTRAŽ. ZAGREB GOD. 21 (2012), BR. 1 (115), STR. $1-17$

VUKASOVIĆ, T., BRATKO, D., BUTKOVIĆ, A.: GÉNETSKI DOPRINOS...
Røysamb, E., Harris, J. R., Magnus, P., Vittersø, J. i Tambs, K. (2002.), Subjective Well-Being. Sex-Specific Effects of Genetic and Environmental Factors. Personality and Individual Differences, 32 (2): 211-223. doi:10.1016/S0191-8869(01)00019-8

Røysamb, E., Tambs, K., Reichborn-Kjennerud, T., Neale, M. C. i Harris, J. R. (2003.), Happiness and Health: Environmental and Genetic Contributions to the Relationship between Subjective Well-Being, Perceived Health, and Somatic Illness. Journal of Personality and Social Psychology, 85 (6): 1136-1146. doi:10.1037/0022-3514.85.6.1136

Silventoinen, K., Kaprio, J., Lahelma, E. i Koskenvuo, M. (2000.) Relative Effect of Genetic and Environmental Factors on Body Height: Differences across Birth Cohorts among Finnish Men and Women. American Journal of Public Health, 90 (4): 627-630.

Stock, W. A., Okun, M. A., Haring, M. J., Miller, W., Kinney, C. i Ceurvorst, R. W. (1982.), Rigor in Data Synthesis: A Case Study of Reliability in Meta-Analysis. Educational Researcher, 11: (6) 10-14. doi:10.3102/ 0013189X011006010

Stubbe, J. H., Posthuma, D., Boomsma, D. I. i De Geus, E. J. C. (2005.), Heritability of Life Satisfaction in Adults: A Twin-Family Study. Psychological Medicine, 35 (11): 1581-1588. doi:10.1017/S0033291705005374

Tellegen, A., Lykken, D. T., Bouchard, T. J. Jr., Wilcox, K. J., Segal, N. L. i Rich, S. (1988.), Personality Similarity in Twins Reared Apart and Together. Journal of Personality and Social Psychology, 54 (6): 1031-1039. doi:10.1037//0022-3514.54.6.1031

Weiss, A., Bates, T. C. i Luciano, M. (2008.), Happiness Is a Personal(ity) Thing: The Genetics of Personality and Well-Being in a Representative Sample. Psychological Science, 19 (3): 205-210. doi:10.1111/ j.1467-9280.2008.02068.x

\section{Genetic Contribution to the Individual Differences in Subjective Well-Being: A Meta-Analysis}

Tena VUKASOVIĆ, Denis BRATKO, Ana BUTKOVIĆ Faculty of Humanities and Social Sciences, Zagreb

The aim of this meta-analysis was to systemize existing knowledge in the field of subjective well-being heritability and to give guidelines for future research in the field. Subjective well-being is a tendency to have a positive cognitive and affective view of one's life. Research in the field of behavioral genetics has shown that individual differences in subjective well-being are partly determined by genes. Depending on the methodology used (research design, questionnaires, statistical analysis) there is variation in the heritability of subjective well-being. For this meta-analysis, inclusion and exclusion criteria were defined and a literature search has been completed with 14 primary studies 
DRUŠ. ISTRAŽ. ZAGREB GOD. 21 (2012), BR. 1 (115),

STR. 1-17

VUKASOVIĆ, T., BRATKO, D., BUTKOVIC, A.: GÉNETSKI DOPRINOS identified. Five studies had to be excluded from the analysis because of dependent data (samples). The average subjective well-being index of heritability shows that $39 \%(k=10$, $Q(d f=9)=241.32, p<0.0001)$ of the phenotype variance can be explained by genetic contribution. After correcting for publication bias, $32 \%(k=12, Q(d f=11)=392.83$, $p<0.0001$ ) of the phenotype variance can be explained by genetic contribution. Guidelines for future research are discussed as well as limitations of this meta-analysis.

Keywords: meta-analysis, heritability, subjective well-being, life-satisfaction, behavioral genetics 